\title{
New Avian Breeding Records for Igloolik Island, Nunavut
}

\author{
NiCOLAS LeCOMte ${ }^{1,2}$ and MARIE-ANDRÉE GIROUX ${ }^{1}$ \\ ${ }^{1}$ Department of Environment, Government of Nunavut, Igloolik, Nunavut X0A 0L0 Canada, and Canada Research Chair in Polar \\ and Boreal Ecology, Department of Biology, Université de Moncton, Moncton, New Brunswick E1A 3E9 Canada \\ ${ }^{2}$ Corresponding author: Nicolas.Lecomte@umoncton.ca
}

Lecomte, Nicolas, and Marie-Andrée Giroux. 2015. New avian breeding records for Igloolik Island, Nunavut. Canadian Field-Naturalist 129(2): 194-196.

New breeding records for three tundra nesting species were documented on the Arctic island of Igloolik (Nunavut, Canada). The species are the Cackling Goose (Branta hutchinsii), the Tundra Swan (Cygnus columbianus), and the Pectoral Sandpiper (Calidris melanotos). These records refine their breeding range in the Canadian Arctic archipelago, while highlighting changes in detected bird communities at specific locations through time.

Key Words: Cackling Goose; Branta hutchinsii; Tundra Swan; Cygnus columbianus; Pectoral Sandpiper; Calidris melanotos; breeding; high Arctic; Igloolik

\section{Introduction}

We conducted fieldwork on Igloolik Island (Nunavut, Canada), about $25 \mathrm{~km}$ from the hamlet of Igloolik from early June to early August in 2012, 2013, and 2014. This island is located in northwest Foxe Basin next to the Melville Peninsula and south of the northern part of Baffin Island. Our main objective was to study the functioning and dynamics of an Arctic food web and measure shorebird sensitivity to perturbations.

We follow the recent example of Hussell et al. (2012), who highlighted the importance of reporting new breeding records in Nunavut to refine our knowledge of wildlife distribution in the Canadian Arctic and report changes in detected bird communities at specific locations over time. While mapping all birds nests in our intensive study area of $0.4 \mathrm{~km}^{2}$ and surveying a larger area of $11.7 \mathrm{~km}^{2}$, we documented new breeding records for the Cackling Goose (Branta hutchinsii), Tundra Swan (Cygnus columbianus), and Pectoral Sandpiper (Calidris melanotos).

\section{Results}

\section{Cackling Goose}

Although many Cackling Geese were seen during migration, only two nests were found in our survey area, on 24 June 2014. One nest and its female are pictured in Figure 1A. The two nests were located on tiny islands in ponds located within wetland patches. Both nests were successful, with four goslings each departing from their nest on 17 and 18 July.

\section{Tundra Swan}

Two flying pairs were seen in the spring of 2012 and 2013. On 15 June 2014, a territory was detected, with a male and female showing territorial displays. At about $100 \mathrm{~m}$ from the territorial pair, an active nest (Figure 1B) was found on 28 June 2014 together with three older nests. The active nest contained four eggs when discovered, but was predated two weeks later.

\section{Pectoral Sandpiper}

Three nesting territories were located in the survey area in June 2012 and June 2013, especially by moni- toring the distinctive hooting calls of the males (Farmer et al. 2013) during all days of June. Unfortunately, the nests are somewhat difficult to find as females hide beside nearby rocks without making any alert calls or displays. Among the three territories located in 2013, one nest with four eggs was found in the intensive study area on 31 June 2014. The male associated with the active nest is pictured in Figure 1C. This nest was depredated a week and a half later. On 21 July, three families of Pectoral Sandpipers were observed in the intensive study area.

\section{Discussion}

Species breeding ranges are dynamic, especially with the ongoing global changes in climate and land use (Parmesan 2006). Although breeding ranges are often portrayed as continuous spatial units, except in the case of recognized disjunct ranges, in reality they are an interpolation of discontinuous observed breeding locations (Fortin et al. 2005). Hence, reporting new breeding locations through various means is important to ensure ongoing refinement and adjustment of ranges, both within and outside known boundaries.

The most recent detailed list of species nesting on Igloolik Island was recorded in 1985-1986, as a result of intensive observation efforts by Forbes et al. (1992), who documented three new breeding species. Together with our study, the list of breeding birds of Igloolik Island now stands at 33 species recorded since the first expedition of Captain Parry in the H.M.S. Hecla in 1821 (Lyon 1824).

The Cackling Goose is a recently recognized species, formerly known as Branta canadensis hutchinsii, a small subspecies of Canada Goose (Branta canadensis). According to the range shown in Mowbray et al. (2002), these tundra-nesting birds are typically found on the Melville Peninsula. Despite intensive harvesting and egg collection activities on Igloolik Island during spring, we found no previous breeding records for Cackling Goose or Canada Goose on the island in eBird (www.ebird.org). Birds seen on Igloolik Island fit the general description of this species: high-pitched calls, overall small size, 


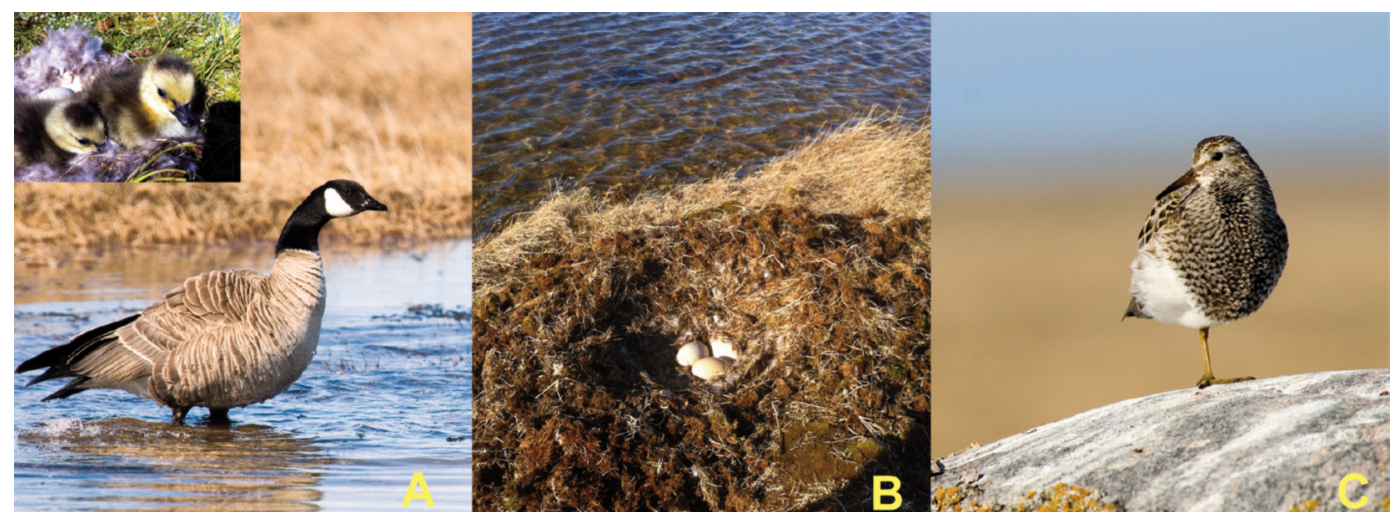

FIgURE 1. New breeding birds in Igloolik, Nunavut, Canada. A. Female Cackling Goose (Branta hutchinsii) with its nest as an insert, 24 June 2014 and 18 July 2014. B. The only Tundra Swan (Cygnus columbianus) nest discovered on the island, 28 June 2014. C. Male Pectoral Sandpiper (Calidris melanotos) in our study area just after a display flight and a territorial call, 5 July 2013. Photos: N. Lecomte.

light-coloured plumage, pale breast, and short bill (about a third of the head length). Cackling Geese were numerous in the area of Igloolik Island during spring migration and are known to nest further north (eBird*). There is even a nearby island called "plentiful Canada Geese" in Inuktitut (Nirlirnaqtuuq). Forbes et al. (1992) reported that Canada Geese were uncommon, with only 13 birds observed in their two-year study compared with the hundreds we saw flying during migration every year (N. Lecomte and M.-A. Giroux, personal observations). Such an increase may reflect the steady population growth of this species since the 1970s, with the population doubling in only 20 years (Mowbray et al. 2002). Igloolik Island is located on the northern margin of the Tundra Swan's distribution (BirdLife International 2012*). Given ongoing global warming, which is especially rapid in the Arctic (Stocker et al. 2013), such a range extension is not surprising (Chen et al. 2011). No breeding record of Pectoral Sandpipers on Igloolik or nearby islands has been documented in eBird. However, in the last two years, evidence of breeding by Pectoral Sandpipers has been documented further north on Baffin, Bylot, and Devon Islands (eBird*). The apparently disjunct distribution in the Arctic Archipelago may be due to a lack of observations in this area.

The paucity of observers in the North compared with southern latitudes hampers our ability to track new species in the North. We recommend reporting observations of breeding locations by completing government checklists such as the Canadian Wildlife Service Northwest Territories/Nunavut checklist survey (https://www.ec.gc.ca/reom-mbs/default.asp?lang=En $\& n=60 \mathrm{E} 48 \mathrm{D} 07-1$ ), entering data into online databases such as eBird, to which the Canadian Wildlife Service contributes by entering the checklist surveys (Canadian Wildlife Service $2007^{*}$ ), or through formal scientific publication. This will help identify new species breed- ing in the tundra and refine breeding ranges, e.g., Hussell et al. (2012). The necessity of consulting local communities to gather new observations, therefore, seems paramount to detecting new species arriving in this large Arctic area.

\section{Acknowledgements}

We acknowledge the community of Igloolik, the Hunters and Trappers Organization of Igloolik, and our field assistants who did outstanding work. Our research is supported by the Canada Research Chair Program, Natural Sciences and Engineering Research Council of Canada (NSERC), the Polar Continental Shelf Program (Natural Resources Canada), the Canadian Foundation for Innovation, the Environorth NSERC Create program, the Canadian Polar Commission, the Arctic Shorebird Demographics Network, Université de Moncton, and the Government of Nunavut, Department of Environment. We are grateful for insightful comments provided by A. J. Gaston and P. A. Smith on an earlier version of the manuscript.

Documents Cited (marked * in text)

BirdLife International. 2012. Cygnus columbianus. The IUCN Red List of Threatened Species. Version 2014.2. Accessed September 2014. http://www.iucnredlist.org /details/22679862/0.

Canadian Wildlife Service. 2007. eBird and the Checklist program are now sharing data. NWT/Nunavut Bird Checklist Survey Newsletter, Spring: 1. Accessed February 2015. http://publications.gc.ca/collections/collection_2011/ec/CW 70-15-2007-eng.pdf.

eBird. National Audubon Society and Cornell Lab of Ornithology, Ithaca, New York. Accessed July 2014. http://ebird .org/ebird/map/.

Farmer, A., R. T. Holmes, and F. A. Pitelka. 2013. Pectoral Sandpiper (Calidris melanotos). In The Birds of North America Online. Edited by A. Poole. Cornell Lab of Ornithology, Ithaca, New York, USA. Accessed August 
2014. http://bna.birds.cornell.edu/bna/species/348.

Mowbray, T. B., C. R. Ely, J. S. Sedinger, and R. E. Trost. 2002. Canada Goose (Branta canadensis). In The Birds of North America Online. Edited by A. Poole. Cornell Laboratory of Ornithology, Ithaca, New York, USA. Accessed August 2014. http://bna.birds.cornell.edu/bna /species/682.

\section{Literature Cited}

Chen, I.-C., J. K. Hill, R. Ohlemüller, D. B. Roy, and C. D. Thomas. 2011. Rapid range shifts of species associated with high levels of climate warming. Science 333: 10241026.

Forbes, G., K. Roberston, C. Ogilvie, and L. Seddon. 1992. Breeding densities, biogeography, and nest depredation of birds on Igloolik island, N.W.T. Arctic 45: 295-303.

Fortin, M.-J., T. H. Keitt, B. A. Maurer, M. L. Taper, D. M. Kaufman, and T. M Blackburn. 2005. Species' geographic ranges and distributional limits: pattern analysis and statistical issues. Oikos 108: 7-17.
Hussell, D. J. T., J. A. T. Hussell, and E. H. Dunn. 2012. New avian breeding records for Iqaluit, Nunavut. Canadian Field-Naturalist 126: 59-60.

Lyon, G. F. 1824. The Private Journal of Captain G. F. Lyon of H.M.S. Hecla during the Recent Voyage of Discovery under Captain Parry, 1821-1823. Imprint Society, London, UK.

Parmesan, C. 2006. Ecological and evolutionary responses to recent climate change. Annual Review of Ecology, Evolution, and Systematics 37: 637-669.

Stocker, T. F., D. Qin, G.-K. Plattner, M. M. B. Tignor, S. K. Allen, J. Boschung, A. Nauels, Y. Xia, V. Bex, and P. M. Midgley. 2013. Climate change 2013: the physical science basis. Working Group I Contribution to the Fifth Assessment Report of the Intergovernmental Panel on Climate Change. Cambridge University Press, New York, New York, USA.

Received 17 September 2014

Accepted 24 March 2015 